\title{
Reckless Money Laundering: Some Reflections on Prevention Regulations and the Duty of Care*
}

\author{
Eduardo Demetrio Crespo \\ University of Castilla-La Mancha
}

Article 301.3 of the Spanish Criminal Code punishes money laundering if the facts prove serious imprudence with the imprisonment of six months to two years and a fine triple the amount. This classification is controversial because of doubts surrounding typical scope which requires clarification of interpretation criteria regarding the duty of care required and the active subject. Although the violation of administrative regulations can serve as an orientation parameter, there is no automatism in this regard.

Keywords: Reckless Laundering, Duty of Care, Especially Obliged Subjects, Deliberate Ignorance, Eventual Intent, Serious Imprudence

\section{INTRODUCTION}

Article 301.3 of the Criminal Code punishes money laundering, if the acts are committed for serious recklessness, with a prison sentence of six months to two years and a fine of two to three times the fine. The reckless money laundering offense type was introduced by LO 8/1992 dated December 23rd, and it is undoubtedly a controversial matter to what extent an eminently intentional offense may be committed recklessly without violating basic principles.

As the specialized doctrine emphasizes, this is a figure not considered by the UN conventions on the matter, such as the 1988 Vienna Convention, the 2000 Palermo Convention or the Merida Convention from 2003, only stating that States can adopt more severe complementary measures. In the 1990 Strasbourg Convention and the 2005 Warsaw Convention of the Council of Europe, on the other hand, there is an interest towards the criminalization of forms of "potential knowledge" regarding the origin of goods, but on an optional basis. An exception to the general trend is also the OAS Model Regulations on Money Laundering Offenses.

\section{OFFENSE TYPE STRUCTURE}

Referral Technique from Article 301.3 Criminal Code to Paragraphs 1 and 2 of the Same Precept Critical Elements

a) Formal compliance with article 12 of Criminal Code 
In Fabián's Opinion, article 301.3 of Criminal Code only complies formally with article 12 Criminal Code, according to which "reckless actions and omissions shall only be punished when expressly provided by law", but at the cost of assigning to the legal operator the obligation to make an interpretative effort similar to that required by the general clauses.

\section{b) Concerns about typical scope}

In addition, it is worth asking what elements of the objective offense type of the money laundering intentional offense are classified recklessness: Only about the awareness of the illicit origin or also about the actual acts of conversion, transmission, and so on of the goods? The prevailing doctrine focuses on the first aspect rather than the second one. Fabián considers in this regard that the formulation of article 301.3 in such generic terms would make it possible to understand that recklessness is also projected on one's own conduct, so that "we could imagine that this precept also punishes those who, for example, unintentionally perform -but violate their objective duty of care- acts of conversion or transmission of goods of fraudulent origin; or also those who, being guarantors, negligently breach their inherent supervision duties and do not prevent them from occurring".

c) Limitation of the possibility of the reckless implementation of some laundering methods in article 301.1 of the Criminal Code, which involves a specific willful intent to conceal the fraudulent origin of goods.

It has been said that article 301.1 is suitable as a basis for reckless money laundering, although this would not mean an essential restriction of the punishable scope, since the conduct described therein are not "an attempt of article 301.2".

However, from a different perspective, it is stated that in fact it is not a matter of the perpetrator acting carefully, but of omitting reckless behaviour in the same sense as that demanded to the malicious conduct. Therefore, for Calderón, what must be taken into consideration is that the individual to whom the rule of determination is addressed must not perform acts that exceed the permitted level of risk and that such exceedance is reflected in the result.

If this line of reasoning is followed, a good part of the problems that have to be faced in this thorny matter are resolved, as from this dogmatic consideration of recklessness - which would in any case have to be subjected to further checks - it is concluded that "in the reckless offense there is no particular objective duty of care", but that the objective offense type is fulfilled when the level of risk legally disapproved for the legal good is exceeded, as also happens in the case of intentional offense types.

\section{Required Duty of Care and the Perpetrator}

Delimitation from Above: Possible Criminal Intent

Its existence is generally admitted by doctrine and jurisprudence, which has considered it compatible with the expressions "knowing" and "knowingly". This is equivalent to, as Blanco states, "knowledge is confirmed when the author has been able to represent to himself the possibility of unlawful origin".

In this context, the Supreme Court uses the building of "willful blindness", according to which a person would act by ignoring the elements of the objective offense type, but having the power and duty to know them. In these cases, the option of recklessness for breach of a duty of care is easily applicable, but also the option of possible criminal intent when the probability that the goods in question have a criminal origin is very high. However, considering that the administrative regulation establishes duties of examination and investigation, whose infraction may give rise to cases of recklessness or possible criminal intent, the possibility of generating an intermediate imputation structure that appeals to willful blindness in the strict sense is discussed.

The exposed jurisprudential doctrine is reiterated in the recent STS 970/2016, dated December 21st, from which we obtained the following extract: 
"Regarding the willful intent in the offense of money laundering, Ruling 1349/2005, of November 17th is pronounced, in which it is declared that the willful intent of the perpetrator is specified in the intention to carry out the typical action consisting in the acquisition, conversion or transmission of goods coming from criminal acts, in this case against public health, with the purpose of concealing their origin. And that the knowledge of the unlawful origin of the goods used in the acquisition, is a subjective element of the offense that can be normally established through a process of induction, which does not imply presumption, but its accreditation according to the logical rules from proven facts. Doctrinally called inference judgments, they arise from external facts and are subject to challenge when their conclusion is not logical or inconsistent with the principles of science or experience."

In Ruling 33/2005, dated January 19th, it is expressed that a direct willful intent is not required, just the possible criminal intent, or even it is enough to place oneself in the willful blindness position, that means, whoever, being able and having to know the nature of the act or collaboration that is being requested, keeps in a situation of not being willing to know, but nevertheless collaborates, is entitled to the penal consequences arisen from acting illegally (SSTS, 236/2003 dated February 17th, 628/2003 dated April 30th or 785/2003 dated May 29th).

Regarding money laundering committed as a result of recklessness, Ruling 1034/2005, dated September 14th, states that in the subjective offense type is replaced the intellectual element of knowledge with the subjective element of serious recklessness. In this offense type, it is not necessary for the perpetrator to know the origin of the goods, but rather, due to the circumstances of the case, it is important that he/she would be able to know them only by observing the precautions proper to his/her activity and, nevertheless, has acted outside such precautions or by failing to observe the duties of care that were required of him/her and those that, even in certain forms of action such as the one we are analyzing in this paper, imposed regulations on him/her to find out the origin of the goods or to abstain from operating on them when their origin is not clearly established.

In the offense types provided for in our Code, responsibility is incurred even by those who act with willful blindness, answering in some cases by way of possible criminal intent, and in others by negligence. And this happens both if there is representation, considering the perpetrator that the criminal origin of the goods is possible and, despite this, he/she acts trusting that the action or masking of their origin will not take place, and when there is no such representation, that is to say, that the possibility of a money laundering offense is not foreseen, but the existence of indications revealing the unlawful origin of the money should have been appreciated. There is a duty to know, which makes it impossible to ignore suspicious circumstances (STS 1257/2009, de 2-12)».

\section{Delimitation from Below: Reckless Negligence}

It is difficult to distinguish between reckless negligence and slight negligence, especially in the case of private individuals who are not subject to specifically assessed duties of care, as is the case with reporting entities bound by Law 10/2010 on the prevention of money laundering and the financing of terrorism. As it could not be otherwise, the judgement must give sufficient and clear reasons for the decision taken.

CALDERÓN has stated that it would be preferable to simply talk about recklessness and that, in any case, when measuring seriousness two aspects must be considered, one qualitative and the other quantitative. In the first case, it would be an excessively unthinking conduct, which occurs because the perpetrator has ignored the circumstances that would have prevented the result. With regard to the second 
one, it should be considered the degree of possibility that the perpetrator had to avoid the occurrence of the result.

\section{Common or Special Offense?}

If the delimitation of "duty of care" depends in each case on whether or not it is a "reporting entity", the question of whether we are dealing with a common or special offense is essential.

The special offense theory is based on the fact that a duty of care in relation to the protection of the legal property of article $301.3 \mathrm{CP}$ does not apply to all citizens in general, but only to "reporting entities" and, on the other hand, it is argued that the opposite would violate the taxativity principle.

The problem that arises from this for citizens who are not reporting entities is that they would only be affected by a possible criminal intent imputation, when, as FABIÁN warns us, "if there were rules of care applicable to them, perhaps their conduct could have been described as reckless".

If we followed this point of view, the preventive regulation's role in the delimitation of duty of care would be of extreme importance, given that the offense type application would in reality depend on the framework delimited by it, inasmuch as the adoption or non-adoption of the measures indicated therein will in turn indicate the exceeding of the permitted level of risk that objectively imputes the offense type realization. In fact, it has been stated that "the most relevant political-criminal function of the BdeC reckless type is to operate as a legal-criminal reinforcement of the duties of cooperation to be performed by professionals, managers and employees of the private sector. In this sense, the administrative law would operate essentially as an execution law of the type of criminal offense.

A general distinction can be made between customer due diligence duties, the duty to report suspicious transactions to the State, the duty to refrain from carrying out suspicious transactions, the duty of confidentiality or the prohibition on disclosing to the customer or to third parties that the State has been informed or that a transaction is under investigation and the duty to keep documents required in compliance with the duty of due diligence to the customer and concerning the business and transactions conducted, and the establishment of internal control policies and procedures to ensure compliance with the aforementioned duties.

However, such restriction is not deduced from the precept of the Criminal Code, consequently a part of the doctrine finds it applicable on the basis of a breach of the duty of care determined by the inadequate adaptation of the conduct to the normal intelligence criterion according to the rules of logic and experience. In fact, the prohibition's scope does not exclude individuals, but, as DÍAZ MAROTO warns, article 301.3 makes no reference to the perpetrator, so it would have to be accepted that it constitutes an offense subtype that can be committed by anyone, given that, in addition, the intentional types to which the reckless person refers are common offenses.

Notwithstanding to the fact that it seems logical that those "called" to commit this type of money laundering are reporting entities, as long as the legislator does not reform the offense type to expressly define it as a "special offense type", any citizen can commit it. This is also understood in case law, as an example of the aforementioned STS 970/2016 dated December 21st, in which it can be read:

"And despite the existing divergences regarding the doctrine, it can be concluded that the case provided for in article 301.3 of the Criminal Code is a common offense, so that it can be committed by any citizen, to the extent that he/she acts in the absence of the socially required care to avoid damage to the protected legal property. Our recent Ruling 749/2015 dated November 13th emphasized that article 301.3 does not make any reference to the perpetrator, so it must be accepted that it constitutes an offense subtype that can be committed by any individual. Since the intentional offense types to which the reckless refers are common types, not expressly differentiated by the legislator, it is not congruent to categorize the reckless modality as a special offense, so that this offense need not be committed exclusively by those on whom the law imposes money laundering prevention measures, but can be committed by any private individual who must be more careful in the handling of funds, given the fact that the money could come from a criminal activity.

Once the previous doctrine has been applied to the analyzed case, it is not possible to ignore the motive. The judgment at first instance describes conduct which, although the court does not classify as 
possible criminal intent, it does consider to be reprehensible by negligence, considering that the appellant could easily have been represented that criminal funds could be used and its origin would be concealed. Facing an appeal that is argumentatively fluctuating between two situations that are absolutely incompatible, since she affirmed both that the appellant's action to constitute a company is a neutral act (which, considered in isolation, did not allow him to perceive the disruption risk to the legal property), and that she believed in the legitimacy of Rogelio's business, (thus demonstrating that he knew all the business reality that surrounded the constitution of the Bell Brogit entity), the fact is that the reality on which the judgment at first instance is based allows us to appreciate in his actions a serious and profound neglect of the revealing signs that a money laundering conduct could be carried out".

\section{Non-compliance of Administrative Rules and Reckless Type}

There is no automatism between non-compliance with administrative regulations and the offense type execution. In this regard, FABIÁN indicates that "neither the mere infraction of administrative regulations necessarily represents an assumption of reckless money laundering, nor the scrupulous compliance of each and every one of them guarantees -as long as we accept the questionable conclusion reached by the Supreme Court in a recent pronouncement- that a reporting entity cannot be condemned for this offense, given that the duties contained in the preventive regulations are eminently formal". Concerning the first part of this statement, no major objections seem to be expressed. In this sense, CALDERÓN states that, in fact, "not every predictability produced by an attack on a legal property is typical", but that it must be verified that certain limits have been crossed: e.g. there is no offense definition when the perpetrator has not created a legally relevant danger, in the same way that whoever acts assuming that others will comply with their duties by virtue of the principle of trust does not infringe the rule. This is because noncompliance with the standard is limited to individual avoidability or personal compliance with the prohibition. On the other hand, the second part would be highly problematic, since under the theory of neutral acts, a professional who scrupulously complies with the rules of prevention should not have to answer criminally.

\section{ACKNOWLEDGEMENT}

Published originally in Spanish: Demetrio Crespo, E., «El blanqueo imprudente: algunas reflexiones sobre normativa de prevención y deber de cuidado», en M. Abel Souto \& N. Sánchez Stewart (Coord.), $V$ Congreso sobre prevención y represión del blanqueo de dinero, Valencia: Tirant lo Blanch, 2018, pp. 217-228 | ISBN: 978-84-9169-686-5.

\section{ENDNOTES}

1. See., among other references, Bajo Fernández, M., «El desatinado delito de blanqueo de capitales», in M. Bajo Fernández \& S. Bacigalupo (Eds.), Política criminal y blanqueo de capitales, Madrid et al.: Marcial Pons, 2009, p. 18; Bermejo, M.G., Prevención y castigo del blanqueo de capitales. Un análisis jurídicoeconómico, Madrid et al.: Marcial Pons, 2015, pp. 325 and ss.; Blanco Cordero, I., El delito de blanqueo de capitales, $3^{\mathrm{a}}$ ed., Cizur Menor (Navarra): Aranzadi, 2012, pp. 724 and ss; Díaz-Maroto and Villarejo, J., El blanqueo de capitales en el Derecho español, Madrid: Dykinson, 1999, pp. 30 and ss.; Fabián Caparrós, E., El delito de blanqueo de capitales, Madrid: Colex, 1998, pp. 415 and ss; Ib., «Algunas observaciones sobre el blanqueo imprudente de capitales (aspectos doctrinales y jurisprudenciales», see Iustitia, No. 8, 2010, pp. 59-86; Ib., «Oportunidad político-criminal y viabilidad dogmática del delito imprudente de blanqueo de capitales», in I. Berdugo Gómez de la Torre \& A.E. Liberatore S. Bechara (Coord.), Estudios sobre la corrupción: una reflexión hispano-brasileña, 2013, pp. 353 and ss; Gómez Iniesta, D., El delito de blanqueo de capitales en Derecho español, Barcelona: Cedecs, 1996, pp. 54 and ss; Palma Herrera, J.M., Los delitos de blanqueo de capitales, Madrid: Edersa, 2000, pp. 587 and ss.

2. Fabián Caparrós, E., «Algunas observaciones...», Op.cit, p.65; Ib., «Oportunidad político-criminal...», Op.cit, pp. 356 and ss. 
3. Fabián Caparrós, E., «Algunas observaciones...», Op.cit, p.67.

4. Fabián Caparrós, E., «Algunas observaciones...», Op.cit, p.69; Ib., «Oportunidad político-criminal...», Op.cit, pp. 362.

5. Fabián Caparrós, E., «Algunas observaciones...», Op.cit, p. 70.

6. Calderón Tello, L.F., El delito de blanqueo de capitales: problemas en torno a la imprudencia y la receptación, Cizur Menor (Navarra): Aranzadi, 2016, p. 91.

7. Calderón Tello, L.F., El delito de blanqueo de capitales..., Op.cit, p. 99.

8. We will not address in this section the special problem of legal persons as perpetrator of money laundering and, in particular, of recklessness. Concerning that, see.: Blanco Cordero, I., El delito de blanqueo de capitales, Op.cit, pp. 845 and ss; Abel Souto, M., «Las reformas penales de 2015 sobre blanqueo de capitales», RECPC, No. 19, 2017 (in press).

9. Blanco Cordero, I., El delito de blanqueo de capitales, Op.cit, p. 686; Arias Holguín, D.P., Aspectos político-criminales y dogmáticos del tipo de comisión doloso de blanqueo de capitales (Art. 301 CP), Madrid: Iustel, 2011, pp. 327 and ss.

10. Bermejo, M.G., Prevención y castigo..., Op.cit, p. 329; Blanco Cordero, I., El delito de blanqueo de capitales, Op.cit, pp. 691 y ss; Fabián Caparrós, E., «Algunas observaciones...», Op.cit, p. 73.

11. Bermejo, M.G., Prevención y castigo..., Op.cit, p. 332.

12. The italics are mine

13. Regarding the new provisions in this point of Directive 2015/849 of the European Parliament and of the Council dated May 20th, 2015, on the prevention of the use of the financial system for the purpose of money laundering and financing of terrorism, See: Lombardero Expósito, L. M., El nuevo marco regulatorio del blanqueo de capitales, Barcelona, Bosch, 2015, pp. 116 and ss.

14. Calderón Tello, L.F., El delito de blanqueo de capitales..., Op.cit, pp. 148-149

15. Ibid.

16. According to the article 2 of Law 10/2010 on the prevention of money laundering and the financing of terrorism are reporting entities, among others, a) Credit institutions; b) Insurance companies authorized to operate in the life branch and insurance brokers when they work in relation to life insurance or other services related to investments, with the exceptions established by regulation; c) Investment service companies; d) Management companies of collective investment institutions and investment companies whose management is not entrusted to a management company; e) Management companies of pension funds; f) Management companies of venture capital entities and venture capital companies whose management is not entrusted to a management company; g) Mutual guarantee societies; h) Payment institutions and electronic money institutions; i ) Persons engaged professionally in currency-exchange activities; $j$ ) Postal services regarding money-transfer activities; k) Persons professionally engaged in intermediation in loan or credit concession, as well as persons who, without having obtained authorisation as financial credit establishments, professionally perform any of the activities referred to in the first Additional Provision of Law 3/1994, dated April 14th, adapting Spanish legislation on Credit Institutions to the Second Banking Coordination Directive and introducing other modifications relating to the Financial System; 1) Real estate developers and those who professionally perform agency, commission or intermediation activities in the acquisition and sale of real estate; $m$ ) Account auditors, external accountants or tax advisors; $n$ ) Notaries and property, mercantile and movable property registrars; $\tilde{\text { n}})$ Lawyers, public prosecutors or other independent professionals when they participate in the conception, performance or advice of transactions on behalf of clients relating to the purchase and sale of real estate or commercial entities, the management of funds, securities or other assets, the opening or management of current accounts, savings or securities accounts, the organisation of necessary contributions for the creation, operation or management of companies or the creation, operation or management of trusts, companies or similar structures, or when they act on behalf of clients in any financial or real estate transaction; o) Persons who, in a professional capacity and in accordance with the specific regulations applicable in each case, provide the following services to third parties: (...); p) The gambling casinos; q) Persons who professionally trade in jewellery, stones or precious metals; r) Persons who professionally trade with art objects or antiques; s) Persons who professionally perform the activities referred to in article 1 of Law 43/2007, dated December 13th, regarding the protection of 
consumers in the contracting of goods with an offer of price restitution; t) Persons who perform activities of professional deposit, custody or transport of funds or means of payment; $u$ ) Persons responsible for the management, operation and marketing of lotteries or other games of chance regarding the payment of prizes; v) Individuals who make movements of means of payment, under the terms established in article 34; w) Persons who professionally trade in goods, under the terms established in article 38; x) Foundations and associations, under the terms established in article 39; y) Managers of payment systems and clearing and settlement of securities and financial derivatives, as well as managers of credit or debit cards issued by other entities, pursuant to the terms established in article 40 .

17. Fabián Caparrós, E., «Algunas observaciones...», Op.cit, p.78.

18. Bermejo, M.G., Prevención y castigo..., Op.cit, p. 325.

19. Bermejo, M.G., Prevención y castigo..., Op.cit, p. 243.

20. Chapter II of the aforementioned Law 10/2010, on the prevention of money laundering and financing of terrorism relates in Section 1 of Chapter II the so-called normal measures of proper monitoring, which include the formal identification of any natural or legal persons wishing to establish business relations or intervene in any operation (article 3), as well as the identification of the beneficial owner (article 4), the gathering of information regarding the purpose and intended nature of the business relationship (article 5) and continuous monitoring of the business relationship (article 6), applying these last ones (articles 4 to 6) according to risk and depending on the type of customer, business relationship, etc., and regardless of any exception or threshold when there are indicators of money laundering or financing of terrorism or when there are doubts about the authenticity or adequacy of previously obtained data (article 7). According to article 8 , reporting entities may have recourse to third parties bound by the same rule for the application of due diligence measures, excluding the continuous monitoring of the business relationship, which does not exempt them from liability since "reporting entities shall maintain full liability with regard to the business relationship or transaction, even when the breach is attributable to the third party, without prejudice, where applicable, to the liability of the third party". Section 2 provides for simplified due diligence measures and Section 3 for enhanced due diligence measures. In any case, the aforementioned are applicable to private banking, money remittance services and foreign exchange operations, and may also be regulated in business areas that involve a higher risk of money laundering or financing of terrorism.

21. Aránguez Sánchez, C., El delito de blanqueo de capitales, Madrid: Marcial Pons, 2000, p. 284.

22. Díaz Maroto y Villarejo, J., «Section 21. Receptación y blanqueo de capitales», in F. Molina Fernández (Coord.), Memento Práctico Penal 2017, Madrid: Francis Lefebvre, 2016, p. 1379.

23. The italics are mine

24. Fabián Caparrós, E., «Algunas observaciones...», Op.cit, p. 81.

25. Calderón Tello, L.F., El delito de blanqueo de capitales..., Op.cit, p. 103.

26. On this complex problem, among other references, see: Pérez Manzano, M., «Neutralidad delictiva y blanqueo de capitales: el ejercicio de la abogacía y la tipicidad del delito de blanqueo de capitales», in Bajo Fernández, M. \& Bacigalupo, S. (Eds.), Política criminal y blanqueo de capitales, Madrid et al.: Marcial Pons, 2009, pp. 169-206; Cuenca García, M ${ }^{\mathrm{a}}$ J., «Reflexiones sobre los actos neutrales y la cooperación delictiva desde los criterios de la imputación objetiva», RP, No. 32, 2013, pp. 141-152. 


\section{REFERENCES}

Abel Souto, M. (2002). El blanqueo de dinero en la normativa internacional, Santiago de Compostela: University of Santiago de Compostela.

Abel Souto, M. (2005). El delito de blanqueo en el Código penal español, Barcelona: Bosch.

Abel Souto, M., \& Sánchez Stewart, N. (Coord.). (2014). Fourth International Congress on the Prevention and Suppression of Money-Laundering, Valencia: Tirant lo Blanch.

Abel Souto, M. (2017). Las reformas penales de 2015 sobre blanqueo de capitals. RECPC, $\mathrm{n}^{\circ}$ 19, (in press).

Almagro Martín, C. (Dir.). (2016). Estudios sobre control del fraude fiscal y prevención del blanqueo de capitales, Cizur Menor (Navarra): Aranzadi.

Aránguez Sánchez, C. (2000). El delito de blanqueo de capitales, Madrid: Marcial Pons.

Arias Holguín, D.P. (2011). Aspectos político-criminales y dogmáticos del tipo de comisión doloso de blanqueo de capitales (Article 301 CP), Madrid: Iustel.

Bajo Fernández, M., \& Bacigalupo, S. (Eds.). (2009). Política criminal y blanqueo de capitales, Madrid et al.: Marcial Pons, 2009.

Bajo Fernández, M. (2009). El desatinado delito de blanqueo de capitales», en M. Bajo Fernández \& S. Bacigalupo (Eds.), Política criminal y blanqueo de capitales, Madrid et al.: Marcial Pons, pp. 1120.

Blanco Cordero, I. (2012). El delito de blanqueo de capitales, $3^{\mathrm{a}}$ ed., Cizur Menor (Navarra): Aranzadi.

Bermejo, M.G. (2015). Prevención y castigo del blanqueo de capitales. Un análisis jurídico-económico, Madrid et al.: Marcial Pons.

Calderón Tello, L.F. (2016). El delito de blanqueo de capitales: problemas en torno a la imprudencia y la receptación, Cizur Menor (Navarra): Aranzadi.

Cuenca García, M J J. (2013). Reflexiones sobre los actos neutrales y la cooperación delictiva desde los criterios de la imputación objetiva. $R P$, No. 32, 141-152.

Mallada Fernández, C. (2015). Guía práctica de prevención del blanqueo de capitales, Cizur Menor (Navarra): Aranzadi.

Díaz Fraile, J.Ma . (Coord.). (2016). Legislación y Jurisprudencia sobre prevención del blanqueo de capitales, Cizur Menor (Navarra): Thomson Reuters.

Díaz Maroto y Villarejo, J. (1999). El blanqueo de capitales en el Derecho español, Madrid: Dykinson.

Díaz Maroto y Villarejo, J. (2016). Section 21. Receptación y blanqueo de capitales», in F. Molina Fernández (Coord.), Memento Práctico Penal 2017, Madrid: Francis Lefebvre, pp. 1362-1384.

Fabián Caparrós, E. (1998). El delito de blanqueo de capitales, Madrid: Colex.

Fabián Caparrós, E. (2010). Algunas observaciones sobre el blanqueo imprudente de capitales (aspectos doctrinales y jurisprudenciales», en Iustitia, No. 8, pp. 59-86.

Fabián Caparrós, E. (2013). Oportunidad político-criminal y viabilidad dogmática del delito imprudente de blanqueo de capitales», in I. Berdugo Gómez de la Torre \& A.E. Liberatore S. Bechara (Coord.), Estudios sobre la corrupción: una reflexión hispano-brasileña, pp. 353-385.

Gómez Iniesta, D. (1996). El delito de blanqueo de capitales en Derecho español, Barcelona: Cedecs.

Lombardero Expósito, L. M. (2015). El nuevo marco regulatorio del blanqueo de capitales, Barcelona, Bosch.

Palma Herrera, J.M. (2000). Los delitos de blanqueo de capitales, Madrid: Edersa.

Pérez Manzano, M. (1994). El tipo subjetivo en los delitos de receptación y blanqueo de dinero. CDJ, (1), 219-251.

Pérez Manzano, M. (2009). Neutralidad delictiva y blanqueo de capitales: el ejercicio de la abogacía y la tipicidad del delito de blanqueo de capitales», en Bajo Fernández, M. \& Bacigalupo, S. (Eds.), Política criminal y blanqueo de capitales, Madrid et al.: Marcial Pons, pp. 169-206. 